\title{
Building a 'Harmonious World': A Mission Impossible?
}

\author{
ZOU KEYUAN
}

\begin{abstract}
In September 2005, President Hu Jintao called for a 'harmonious world' at the summit for the 60th anniversary of the founding of the United Nations. Following his call, the Chinese government issued a white paper on China's peaceful development road, in which 'building a harmonious world' is valued as the 'lofty goal' in taking the path of 'peaceful development'. In the latest Five-Year Plan (2011-2015), Chinese foreign policy continues to hold high the banner of peace, development and cooperation and to build a harmonious world featured by enduring peace and common prosperity together with other countries in the world. This article will examine the doctrine of 'harmonious world' to see whether it is practical in conducting international relations between China and the rest of the world and how China should adjust its foreign policy thinking to better cope with the more complicated world. It is timely and meaningful to discuss the topic at the time when China changes its leadership. ${ }^{1}$
\end{abstract}

\section{Introduction}

As we know, any society would become chaotic if there were no public order and chaos is definitely contrary to harmony. The same applies to the international society. After World War II, a new international order centred on the United Nations system was established. The United Nations Charter reiterated a series of fundamental principles governing international relations, including the principle of sovereign equality, of peaceful settlement of international disputes, and of refraining from the threat or use of force against the territorial integrity or political independence of any state. ${ }^{2}$ Despite the passage of time, the essence of this world order remains alive today.

While China called for the establishment of a new international economic and political order, what China really means is the reform of the existing order rather than fundamentally changing such an order. Being a UN member, China is bound by the Charter of the United Nations, 
including the general principles contained in the Charter, so as to carry out its corresponding obligations under the Charter. ${ }^{3}$ As we can see from the Chinese practice in international relations, China has always upheld the principles of the United Nations and generally supported the actions taken by this organization since it joined the UN in 1971.

In recent years, China has called for the building of a harmonious world. How is such a harmonious world built? Is it a utopia or reality? This article attempts to discuss and assess the doctrine of harmonious world in the context of China's practices in international relations and look into how China should adjust its foreign policy thinking to better cope with the more complicated world.

\section{Inception and Development of the 'Harmonious World' Doctrine}

In September 2005, President Hu Jintao called for a 'harmonious world' at the summit for the 60th anniversary of the founding of the United Nations. ${ }^{4}$ He expounded on the concept by making a four-point proposal: (1) multilateralism should be upheld to realize common security; (2) mutually beneficial cooperation should be upheld to achieve common prosperity; (3) the spirit of inclusiveness must be upheld to build a world where all civilizations coexist harmoniously and accommodate each other; and (4) the UN needs rational and necessary reform to maintain its authority, improve its efficacy and give a better scope to its role in meeting new threats and new challenges (Xinhua News Agency 2005).

Following his call, the Chinese Government issued a white paper on China's 'Peaceful Development Road' in December 2005, in which 'building a harmonious world' is valued as the 'lofty goal' in taking the path of China's 'peaceful development'. ${ }^{5}$ In the latest Five-Year Plan (2011-2015), ${ }^{6}$ Chinese foreign policy continues to hold high the banner of peace, development and cooperation and to build a harmonious world featured by enduring peace and common prosperity together with other countries in the world.

The latest development on the doctrine of harmonious world can be seen from the white paper on 'Peaceful Development' issued on 7 September 2011. The white paper claims that 'the Chinese civilization has a unique feature of being enduring, inclusive and open' and 'China's overall goal of pursuing peaceful development is to promote development and harmony domestically and pursue cooperation and peace internationally' (Information Office of the State Council 2011). Following 
that overall goal, China will continue to promote the construction of a harmonious world as reflected in its 2011 white paper.

First, China pledges that its foreign policy should 'uphold world peace and promote common development'. In this regard, 'China advocates the building of a harmonious world of durable peace and common prosperity and works with other countries in pursuing this goal' (ibid).

Second, the white paper summarizes five aspects of efforts to build a harmonious world (Information Office of the State Council 2011): (1) Politically, 'countries should respect each other and treat each other as equals, and work together to promote democracy in international relations'. While it is emphasized that 'countries should safeguard the UN's core role in handling global affairs, adhere to the purposes and principles of the UN Charter, abide by international law and the generally-accepted principles governing international relations, and promote democracy, harmony, coordination and win-win spirit in international relations', China sticks to its dogma that the internal affairs of a country should be decided by its own people. (2) Economically, countries should cooperate with each other, draw on each other's strengths and make economic globalization a balanced and win-win process that benefits all countries'. China favours establishing an international multilateral trading system that is fair, open, equitable and non-discriminatory so that the benefit of economic globalization will cover all countries. (3) Culturally, countries should draw on each other's strengths, seek common ground while putting aside differences, respect the diversity of the world, and promote progress in human civilization. (4) With respect to security, countries should trust each other and strengthen cooperation, settle international disputes and conflicts peacefully rather than resorting to war and jointly safeguard world peace and stability. (5) In terms of environment protection, all countries should help each other and make concerted efforts to better protect our only home-the Earth. Countries should develop new modes of development, take the path of sustainable development and promote the harmonious development of man and nature. Based on the above, China will actively enhance 'friendly cooperation with its neighbours and work with them to promote a harmonious Asia'. ${ }^{7}$

What is harmony in China's perception? One explanation defines harmony as 'coordination, combination, integration and peace among different elements' (Harmonious World 2007). In applying it to China's diplomatic thinking, three points have been made to explain the 'harmonious world': First, the harmonious coexistence of all nations 
is the basis for the doctrine of harmonious world (Li Baozheng 2010: 100). Peace is the prerequisite for human beings to realize their societal development goals. Without peace, there is no way to promote new construction, even the achieved fruits would be destroyed in wars $\mathrm{Hu}$ 2005). Second, the harmonious progress of different civilizations is the ultimate goal for the doctrine of harmonious world (Li Baozheng 2010: 100). As Hu pointed out, the diversity of civilizations is a basic characteristic of the human society and the dynamic force of the civilized progress of human beings. The differences in history, culture, social systems and developmental models should not become the barrier to communication among nations, nor a reason for mutual confrontation (Hu 2005). Third, the harmonious development of the global economy and the realization of common prosperity is the core of the doctrine of harmonious world (Li Baozheng 2010: 101). Development is concerned with the vital interest of all peoples and with the elimination of the causes of threats to global security. The world would not enjoy peace without universal development and common prosperity (Hu 2005).

According to a prominent Chinese scholar, harmony is rooted within an order, which is reflected in international relations as a way that all nations coexist peacefully. On the other hand, harmony connotes consultation. One of the important foundations to build a harmonious world is to pursue and create 'shared interests' of all countries. Without this common basis of interests, consultation and cooperation would not be possible (Zhang Yunlin 2008: 11). As asserted above, China's highest goal is to build a harmonious world. The transformation of China's development model can promote world harmony in at least two ways: to help the formation of the balanced world pattern and to help common development (Liu Dongguo 2009: 154).

According to some Chinese scholars, the concept of 'harmonious world' is the first comprehensive strategic ideal the Chinese government has initiated for the future international order. 'It is not merely a thought or a Utopian ideal. It is logically related to the philosophy of "coordination and harmony among all nations" in Chinese traditional culture' (Su Hao 2009: 54).

What is the motivation for China's call for a 'harmonious world'? Why did Hu Jintao put forward this call? There are two reasons to explain the motivation behind it. First, China realizes that there are numerous conflicts and contradictions existing in the current world, which constitute a negative force to the promotion of peace and prosperity. Thus, current human society is far from a harmonious 
world. A call for building a harmonious world can in fact safeguard the purposes and principles of the UN Charter to move forward to a better world that humankind is longing for. Second, in Chinese politics, when a new leadership comes to power, it usually creates new ideological jargon as a yardstick to implement the relevant policy. The leadership led by $\mathrm{Hu}$ Jintao put forward harmonious society and harmonious world with special reference to China's foreign policy. Finally, the Chinese leadership has realized that the concept of peaceful rise or peaceful development may not work effectively in China's international relations. There is a need for a new concept that would have a ground-breaking effect to further enhance China's good image in the world. This can be seen from the fact that peaceful rise has been replaced with peaceful development. Nevertheless, there is an inherent linkage between harmonious world and peaceful rise/development, which will be discussed below.

\section{From Peaceful Rise to Peaceful Development}

The term 'peaceful rise' was first introduced by Zheng Bijian, former executive vice president of the Central Party School, in his speech at the Boao Forum in November 2003. It was later endorsed by the Chinese top leaders $\mathrm{Hu}$ Jintao and Wen Jiabao as a national development strategy, particularly relating to China's link to the international arena. ${ }^{8}$ According to this, China pursues its soft power in the world mainly by using its economic leverage and seeking a peaceful environment for its economic development. Clearly, the doctrine of 'peaceful rise' takes the function of counterbalancing the prevailing jargon in the Asia-Pacific region, i.e., the 'China threat'. To appease its neighbours, China, on many occasions, has reiterated that it will never seek to become a hegemon. However, while taking China's gesture as embodying a good intention, China's rise, whether peaceful or not, still scares its neighbours as its military capability has been ever expanding with the pace of its economic growth. For China, peaceful rise is really a good term, favourable for its development, but for its neighbours, particularly the ASEAN countries, China has already become their 'peaceful' rival, but not a threat, in competing for markets and investment to some extent.

As the term 'peaceful rise' is too strong and leading to negative interpretations, China introduced a new term, 'peaceful development', to replace the former. According to $\mathrm{Hu}$ Jintao, peace and development remain the main themes of our era; seeking peace and promoting devel- 
opment and cooperation have become the irresistible trend of our time (Hu 2007). Chinese foreign policy is then following the main thread of 'peaceful development'. During the 11th Meeting of Diplomatic Envoys held from 17 to 20 July 2009, President Hu Jintao made an important speech indicating the direction of China's new foreign policy. While emphasizing the theme of peace and development and the overall strategy of China's diplomacy, ${ }^{9} \mathrm{Hu}$, for the first time, put forward the 'area diplomacy' concerning global issues such as financial crisis, energy security and climate change to increase China's say in world affairs (Chen 2009).

Likewise, the emergence of the concept of 'harmonious world' marks a shift in the leaderships' understanding of China's position in the world and its overall international strategy (Zheng \& Tok 2007: 4). In comparison with Deng Xiaoping's taoguang yanghui (hiding one's capacity while biding one's time), the idea of 'harmonious world' is more active and 'suggests an increasingly confident China relinquishing its aloofness to participate and undertake greater responsibilities in international affairs' (Zheng \& Tok 2007: 9). In realizing the doctrine of 'harmonious world', China has adopted three diplomatic strategies: universally friendly diplomacy concurring with the Chinese world view 'unity with diversity'; outward-looking regionalism, which is a major trend in the development of international relations; and global inter-regional cooperation based on global international relations to be an inter-coordinating and harmonious new international order ( $\mathrm{Su} H a O$ 2009: 54-55). It is thus clear that China has further promoted its foreign policy based upon peaceful development by calling for the building of a harmonious world.

\section{Roots of the Doctrine}

The doctrine of 'harmonious world' has several roots. First of all, it can be attributed to communism. The ultimate goal of a communist party is to realize a world where everyone is equal in society and the distribution of material wealth is based on need. The Chinese Communist Party is no exception. As stipulated in the Chinese Constitution,

Under the leadership of the Communist Party of China and the guidance of Marxism- Leninism and Mao Zedong Thought, the Chinese people of all nationalities will continue to adhere to the people's democratic dictatorship and follow the socialist road, steadily improve socialist institutions, develop socialist democracy, improve the socialist legal system and work hard and 
self-reliantly to modernize industry, agriculture, national defence and science and technology step by step to turn China into a socialist country with a high level of culture and democracy'. ${ }^{10}$

It is claimed that the doctrine of harmonious world has reflected the pursuit of internationalism by the Chinese Communist Party, but in comparison with the earlier internationalist idealism, the doctrine of harmonious world has a solid basis of realism from the scientific judgement of the international situation and China's power (Ye Qing 2011: 14). It is also claimed that the doctrine reflects communism as it emphasizes the wholeness of the world and concerns the destiny of humankind. It exceeds narrow national or state interests and the realist thinking based on power and interest (Ye Qing 2011: 15).

In addition, some Chinese scholars interpret a harmonious society as one in which all people will do what they are capable of doing as individuals to contribute to the society and are granted the opportunity or position to do so. This interpretation reminds people of the ideal society in Utopia and the definition of an ideal communist society (Han Ai Guo 2008: 148).

\section{The Doctrine of 'Harmonious Society'}

The doctrine of 'harmonious society' was first put forward in 2004 after the $\mathrm{Hu}-\mathrm{Wen}$ administration came to power. ${ }^{11}$ It aims at building the Chinese society into a harmonious society. With the economic reform and growth, disparities in Chinese society are getting wider. According to the UNDP, the average Gini coefficient for Asia is 38.6 while it is 46.9 in China (cited in Paus, Prime \& Western 2009: 10). China's national strategy of balanced development and a harmonious society is designed to address inequalities and political backlash, to refocus China's resources toward those who are relatively poor and to improve the social welfare net (Paus, Prime \& Western 2009: 10, 12). In that sense, the doctrine of 'harmonious world' is just an extension of that of 'harmonious society'. Chinese modernization rests upon two basic goals, i.e., internal harmony (harmonious society) and external harmony (harmonious world) (Zhang Yunlin 2008: 11).

According to the latest White Paper on Peaceful Development, China will accelerate the building of a harmonious society with emphasis on improving people's lives, thus strengthening the foundation of achieving social harmony. It will accelerate the reform of social systems, improve basic public services, develop new mechanisms for social management and make 
such management more efficient, and improve income distribution and the social security system. Our goal is to ensure that all people have the right to education, employment and pay, medical and old-age services and housing, so that all the people share the responsibility of creating a harmonious society and enjoy life and the full benefit of development in such a society. (Information Office of the State Council 2011)

\section{Confucianism}

Confucius discussed 'harmony' in his Analects: 'In the practice of the rites harmony is regarded as the most valuable thing, and in the ways of the ancient kings this is regarded as the most beautiful thing. It is adopted in all matters, both small and great...' (1993: 4). One of the essences in Confucianism is $l i$ (ritual). According to $l i$, the hierarchical structure in a civil society is built on five natural relationships: father and son, ruler and subject, husband and wife, elder and younger and the relationship between friends. Accordingly, the latter should obey the former and the lower part should obey the higher part (Pan Junwu 2010: 3). Li therefore encourages people to exercise proper social behaviour so that a harmonious society can be cultivated (Pan Junwu 2010: 2). Another essential element in Confucianism is he, as Confucius expounded the concept of 'harmony without uniformity', meaning that the world is full of differences and contradictions, but the righteous man should balance them and achieve harmony (Harmonious World 2007).

According to the latest White Paper on Peaceful Development, The world has been believed to be a harmonious whole in the Chinese culture ever since the ancient times. This belief has a lasting impact on the thinking and acts of the Chinese nation, which is an important value that the Chinese people follow in handling interpersonal relationships, the relationship between man and nature and relations between different countries. (Information Office of the State Council 2011)

The Chinese people have always cherished a world view of 'unity without uniformity', 'harmony between man and nature', and 'harmony is invaluable'. This belief calls for the fostering of harmonious family bonds, neighborhood harmony and good interpersonal relationships. (ibid)

\section{Five Principles of Peaceful Coexistence}

Finally, it is worth mentioning the famous 'Five Principles of Peaceful Coexistence', which include: (1) mutual respect for each other's sov- 
ereignty and territorial integrity; (2) non-aggression; (3) non-interference in each other's internal affairs; (4) equality and mutual benefit; and (5) peaceful coexistence. The Five Principles first appeared in the Agreement between the Republic of India and the People's Republic of China on Trade and Intercourse between Tibet Region of China and India signed on 29 April 1954. ${ }^{12}$ Since then, they have been reiterated in China's foreign policy documents as well as agreements, declarations and joint statements signed between China and other countries that are willing to incorporate those principles into the relevant documents. According to one source, from 1954 to 1995, there were more than 150 such documents (Wang 1995: 60). Thus in China's view, these principles have become the universally applicable principles among states, and thus the fundamental principles of international law.

As China claims, the Five Principles constitute the basis for China to have established and developed diplomatic relations with 165 countries, carried out trade, economic, scientific, technological and cultural exchanges and cooperation with over 200 countries and regions, resolved the boundary issues with neighbours and maintained peace and stability in its surrounding areas (Wen 2004).

However, it is time to reconsider whether there is a necessity for China to obsessively stick to these principles as the term 'peaceful coexistence' carries a meaning of passive attitude towards international cooperation and development of international friendly relations. After the Cold War, what is more important and necessary is not merely 'coexistence', but active cooperation and integration. Only through this can global issues such as terrorism and global warming be effectively tackled and solutions can be found. It should be noted that the Five Principles have always been highly regarded in China, despite changes in time as well as in political and diplomatic environments since the founding of the People's Republic of China in 1949. ${ }^{13}$

In China's official view, the Five Principles are the basis for and the precondition to build a harmonious world as they have been accepted throughout the world. Building of a harmonious world not only requires the maintenance of peace and the realization of peaceful coexistence, but also promoting harmony, cooperation and common prosperity so as to realize harmonious coexistence. In that sense, the level of harmonious coexistence is higher than that of peaceful coexistence (Li Baozheng 2010: 99). 


\section{China's Efforts}

After applying the doctrine of 'harmonious world', China has made a series of efforts in that direction. Big events include the Beijing Olympics in 2008 and the Shanghai Expo in 2010. China began to promote Chinese culture following the 'harmonious world' doctrine. ${ }^{14}$ Over 500 Confucius Institutes so far have been set up around the world to spread Chinese language and culture. This can be seen as a concrete measure of soft power build-up. China's efforts can also be seen in Asia, Africa and Latin America, particularly with its developing counterparts. According to one author, in East Asia, China tries to build a harmonious environment with its neighbouring countries for common development; in Africa, it tries to redefine its 'old brotherhood' with African countries, and tries to 'exhibit' its own political values in Latin America where undemocratic or semi-authoritarian regimes remain common (Sheng Ding 2008: 210). ${ }^{15}$ Nevertheless, the most successful effort is on the economic side (Blanchard 2008).

\section{Economic Integration}

Economically, China is now one of the most significant trading countries, and its economy threatens to overtake the largest economy in the world, that of the US, in the not too distant future. Most importantly, its consistent two-digit growth rate in the last three decades has also made the Chinese economy the fastest growing economy in the world. Since its accession to the World Trade Organization (WTO), its GDP has grown more than 10 per cent annually. ${ }^{16}$ China has also been one of the largest recipients of foreign direct investment (FDI) inflow for many years, ${ }^{17}$ and certainly is going to stay that way for the years to come.

A most significant development in China's integration into the world is China's decision to join the WTO. China applied for restoration of its membership in GATT as early as 1986, but only became a formal member of the WTO on 31 December 2001. By entering into the WTO, China is obligated to meet the legal requirements set forth by the WTO and to implement the legal principles such as transparency and accountability. Internally, China needed to bring its relevant laws and regulations in line with those of the WTO, in particular those governing economic activities such as foreign investment, foreign trade and banking. Externally, China signed more international treaties to further open itself to the world community. China is also a member state of the World Bank and the 
International Monetary Fund. China contributed to the establishment of a development bank under the aegis of the Group of 77.

China still advocates the establishment of a new international economic order. During the UN Millennium Summit held in September 2000, Jiang Zemin, then the Chinese president, made an important speech expounding China's position to establish a just and reasonable international political and economic order. China is concerned with the serious imbalance in economic development between North and South. China's status as a market economy is not recognized by the United States and the European Union and China's voting rights in the IMF are only 3.72 per cent, behind Canada, France, Germany, Italy, Japan, UK, and far behind the United States which owns 16.83 per cent, a de facto and decisive veto power in the decision-making of the organization. With the increase of its economic power, China began to complain about the voting rights in international financial organizations such as the IMF. In its Position Paper at the 63rd Session of the United Nations General Assembly in 2008, China called for an international financial reform that 'should focus on reflecting the changes in the world economic pattern, increasing the say and representation of developing countries, reducing their risks in participating in economic globalization and shaping an institutional framework that is conducive to sound and sustainable development of the world economy'. ${ }^{18}$ During the G20 Summit held in September 2009, China expressed several of its concerns about how to monitor speculative trans-border transfer of assets; to increase the voice of developing countries in the IMF and other international organizations; and to enhance the role of special drawing rights in the IMF so as to decrease world dependence on the US dollar. It is reasonably assumed that '[i]f a new Bretton Woods conference were held today, it is clear that delegates would design a different IMF, because both attitudes and circumstances are fundamentally different than they were at the end of World War II' (Dodge \& Murray 2006: 364).

The focal shift from the G8 to the G20 in managing world economic affairs is a remarkable change in North-South relations. It reflects the fact that developing countries, particularly the large ones, can now play an indispensable role in world economic management. The world economic organizations have agreed to increase voting rights of the developing countries to above 5 per cent in the IMF and 3 per cent in the World Bank (People's Daily 2009a: 3), although the increase is not big enough. As expressed by the Chinese foreign minister, China will continue its support for the construction and development of the G20 
mechanism (Yang Jiechi 2011: 2). On the other hand, the international regime for economic and financial arrangements still remains in the hands of the Western countries led by the United States and the existing international economic order will not have a fundamental change in the foreseeable future.

The other pillar in China's advocacy of the establishment of a new international economic order is South-South cooperation, as one key element in China's foreign policy. During the Third UN Conference on the Law of the Sea, China usually sided with the G77 regarding the establishment of a new maritime order enshrined now in the 1982 UN Convention on the Law of the Sea.

In recent years, with the increase of its economic power, China has also increased its financial aid to developing countries. In September 2009, China adopted six important measures to assist the developing countries in agriculture, food aid, education and training, health, sanitation, energy, debt remission, and zero tariffs. According to these measures, China will increase the number of agricultural technical model centres to 30 and experts and technicians to 2,000; China will contribute US\$30 million to the Food and Agriculture Organization (FAO) to set up a trust fund to enhance the agricultural productivity of developing countries; export grain to developing countries with food shortages; increase scholarships to 10,000 to students from developing countries studying in China and train 1,500 principals and teachers from Africa; remit due debts owed by the least developed countries and give them zero tariff treatment for 95 per cent of their products exported to China; and help to develop and utilize clean energy by building 100 clean energy projects in developing countries in the next five years (People's Daily 2009b: 3).

During the Asian financial crisis in 1997, China maintained the value of its currency, which helped Southeast Asian countries stabilize their financial systems and was appreciated by those countries. China was among the first to rush in with an offer of aid - US $\$ 1$ billion in standby credit (Vatikiotis 2003: 69). The crisis, on the other hand, helped Southeast Asia realize the necessity to establish a regional economic integration system so as to prevent such a crisis in the future. Economic integration began first within the ASEAN and was then enlarged to include other countries in Asia. On 1 January 2011, the ASEAN-China Free Trade Zone was formally established. 


\section{Peacekeeping Operations}

As China firmly sticks to its Five Principles of Peaceful Coexistence, it has pledged not to intervene in the internal affairs of any other country and opposes such intervention by other big powers. However, in recent years there has been a subtle change in China's position regarding sovereignty and humanitarian intervention. Intervention may be considered acceptable 'under exceptional circumstances, such as when a national government practices racist policies, kills its people en masse, or collapses only to leave slaughtered people in its wake' (Jia Qingguo 2003: 31). Furthermore, China supports international intervention sponsored and/or authorized by the United Nations and has sent troops to join UN peacekeeping forces in recent years.

China's White Paper on National Defence in 2008 recorded China's involvement in UN peacekeeping activities:

Since 1990 the PLA has sent 11,063 military personnel/time to participate in $18 \mathrm{UN}$ peacekeeping operations. Eight lost their lives on duty. As of the end of November 2008, China had 1,949 military peacekeeping personnel serving in nine UN mission areas and the UN Department of Peacekeeping Operations. Among them, there were 88 military observers and staff officers; 175 engineering troops and 43 medical personnel for the United Nations Organization Mission in the Democratic Republic of the Congo (UNMONUC); 275 engineering troops, 240 transportation troops and 43 medical personnel for the United Nations Mission in Liberia (UNMIL); 275 engineering troops, 100 transportation troops and 60 medical personnel for the United Nations Mission in the Sudan (UNMIS); 275 engineering troops and 60 medical personnel for the United Nations Interim Force in Lebanon (UNIFIL); and 315 engineering troops for the African Union/United Nations Hybrid Operation in Darfur (UNAMID). Since 2000, China has sent 1,379 peacekeeping policemen/time to seven mission areas. At present, 208 Chinese peacekeeping policemen are in Liberia, Kosovo, Haiti, Sudan and East Timor for peacekeeping operations. ${ }^{19}$

It is clear that China now does not totally oppose third party intervention and supports such intervention under the authorization of the United Nations. Sending warships to the Somali waters can also be seen as an intervention to maintain peace and security in that region.

In June 2008, the United Nations Security Council passed a resolution on combating acts of piracy and armed robbery off Somalia's coast (Resolution 1816). ${ }^{20}$ It defines piracy for the first time as a matter threatening international peace and security and authorizes UN member states to enter the territorial waters of Somalia for the purpose of repressing acts of piracy and armed robbery at sea, in a manner consistent with such 
action permitted on the high seas with respect to piracy under relevant international law. ${ }^{21}$ Following the resolution, relevant states, especially a number of European Union countries, Canada, Russia and the United States, have taken individual and/or collective actions against piracy in the waters off Somalia. The Combined Maritime Forces led by the United States established Combined Task Force 151 (CTF-151) in January 2009 to conduct counter-piracy operations in and around the Gulf of Aden, the Arabian Sea, Indian Ocean and the Red Sea. The European Union launched naval operations against Somali piracy under the European Security and Defence Policy framework called EU NAVFOR (Operation Atalanta). Several Asian countries have also sent warships to the Somali waters for the purpose of piracy prevention and suppression.

China showed its reluctance at the beginning. During the discussion of the draft UN resolution, China expressed its opinion that the facilitation initiated by the Council, of international assistance in combating piracy, should not produce any negative consequences and such assistance must comply with the Law of the Sea Convention and must not constitute conflict with existing international legislation (United Nations 2008).

However, it seems that China's attitude was changed somewhat after its vessels were kidnapped by Somali pirates and the ambassador of the Somali government to Beijing said he welcomed the Chinese navy to Somali waters. At a special conference sponsored by the UN in December 2008, the Chinese representative expressed China's willingness to cooperate with other countries to suppress piracy in accordance with international law and the UN Security Council resolutions. ${ }^{22}$ In January 2009, China decided, for the first time, to send warships overseas to the sea areas around Somalia contributing to the international efforts to crack down on Somali piracy. The Chinese naval fleet, consisting of two destroyers and a large supply vessel, completed its first escort mission on 6 January 2009 for four Chinese merchant ships. As expressed by the Foreign Ministry spokesman on 20 December 2008, the task of the Chinese navy is to protect Chinese ships and crews on board as well as ships carrying humanitarian relief materials provided by international organizations including the World Food Programme, in strict compliance with the UN Security Council resolutions and international law. According to a circular issued by the Ministry of Transport, Chinese merchant vessels, including those from Hong Kong, Macao and Taiwan, can apply through the Chinese Association of Ship-owners, for a naval escort when entering the Gulf of Aden and Somali sea area. 


\section{China's Setbacks}

Despite China's efforts, some setbacks have occurred in recent years. According to a recent survey in Japan, more than 70 per cent of Japanese have a bad impression of China. The recent assertive moves in the South China Sea invited serious criticism from the world community.

\section{Climate Change}

China has become the country with the most emissions. For that reason, China is a most important player in the establishment and implementation of the new global climate change regime. As a developing country, China has no compulsory duty to reduce greenhouse gas emissions under the existing international climate change regime, though domestically China has made a series of reduction efforts.

In response to international pressure, China emphasizes the principle of 'common but differentiated responsibilities' (Halvorssen 2007) embodied in the UNFCCC and Kyoto Protocol, as recently expounded by the Chinese Foreign Minister Yang that the basic principles embodied in the UNFCCC and Kyoto Protocol, including the 'common but differentiated responsibilities', constitute the basis for climate change cooperation in the world community. According to Yang (People's Daily 2007: 3), global climate change is caused mainly by long-term historic emissions as well as the current high per capita emissions of the developed countries. Thus, after 2012 the developed countries should continue to bear the emission reduction obligation and to strengthen technology transfer to developing countries. Greenhouse gas historic emissions from developing countries are not high and their current emissions belong to survival emissions and emissions for economic development, thus the means and methods for them to adapt the global climate change regime is to develop and implement sustainable development strategies as well as participate in Clean Development Mechanism (CDM) cooperation. In Hu Jintao's speech to the UN Summit on Climate Change in September 2009, he promised that China would fight for a significant cut in carbon emissions including the following measures: (a) to intensify efforts to conserve energy and improve energy efficiency through a cut of carbon dioxide emissions per unit of GDP by a notable margin by 2020 from the 2005 level; (b) to develop renewable energy and nuclear energy by increasing the share of non-fossil fuels in primary energy consumption to around 15 per cent by 2020; (c) to increase forest carbon sink through the increase of 
forest coverage by 40 million hectares and forest stock volume by 1.3 billion cubic meters by 2020 from the 2005 levels; and (d) to develop the green economy, low-carbon economy and circular economy, and enhance research, development and dissemination of climate-friendly technologies (Hu 2009).

The limits set forth in the Kyoto Protocol expired in 2012. For that reason, the world community needs to negotiate and formulate a new deal for the emission reduction scheme. It is unknown whether China would accept compulsory reduction under a post-Kyoto regime, which is currently being negotiated by world community members. China has realized that there are difficulties for developing countries in the climate negotiations since they 'lack the necessary technical capacity and human resources to back up their negotiations' (Xue Hanqin 2007: 88). Clearly, large developing countries like China have received tremendous pressure from the international community requesting them to bear more responsibilities in the response to climate change. We have to see whether China will make concessions in the future climate negotiations and accept some mandatory emission reduction targets. In the climate cooperation with the United States, China views it as a good opportunity on the one hand, and tries to formulate an atmosphere of 'harmonious competition' on the other (Pan Jiahua 2009: 42-44).

\section{The South China Sea}

The dispute over the Spratly Islands is complicated since it has been lingering for a long time and involves as many as six contesting parties, i.e., China, Chinese Taiwan, Malaysia, Vietnam, the Philippines, and Brunei. It is not usual in the history of international relations that so many countries make claims over the small islets and their surrounding waters.

As a key player, China's efforts and cooperation are indispensable in diffusing tensions in the South China Sea. When it came to the negotiation of a code of conduct for the South China Sea, China, at the beginning, was very reluctant to do it at a multilateral level with ASEAN, though it had a bilateral code of conduct with the Philippines since 1995. Nevertheless, China gradually changed its attitude and began to consider the possibility and benefits of negotiating a code of conduct at the regional level. The change may have resulted from two forces, either internal or external. Internally, China carries out a pragmatic foreign policy, and 'stabilizing the neighbouring regions' (wending zhoubian) is 
one of its top priorities. Based on this, China had to maintain a stable environment in the South China Sea. Externally, the pressures and efforts made by ASEAN countries convinced the Chinese that cooperation with ASEAN was inevitable if China desired stability in the South China Sea. As a result, China put forward its own proposal for a code of conduct in 1999 as a response to the ASEAN one (Hainan Research Institute for the South China Sea 2002: 180-183). There were differences between the two proposals and the two sides negotiated to reach an agreed document. ASEAN countries together with China have held several rounds of discussion to formulate a code of conduct for the South China Sea (ibid). ${ }^{23}$

On 4 November 2002, China and all of the ASEAN member states signed the 'Declaration on the Conduct of Parties in the South China Sea' (the 2002 Declaration) in Phnom Penh, Cambodia. ${ }^{24}$ The declaration is designed to consolidate and develop the friendship and cooperation existing between China and ASEAN, to promote a peaceful, friendly and harmonious environment in the South China Sea, and to enhance the principles and objectives of the 1997 Joint Statement of the Meeting of the Heads of State/Government of the Member States of ASEAN and President of the People's Republic of China.

The Declaration reaffirms the parties' commitment to the use of international law, in particular the Law of the Sea Convention, to conduct confidence building and cooperation. The parties ensure the freedom of navigation in and overflight above the South China Sea. They intend to cooperate in the following matters: (a) marine environmental protection; (b) marine scientific research; (c) safety of navigation and communication at sea; (d) search and rescue operation; and (e) combating transnational crime, including but not limited to trafficking in illicit drugs, piracy and armed robbery at sea, and illegal traffic in arms.

They promise to resolve their territorial and jurisdictional disputes by peaceful means, without resorting to the threat or use of force, and to continue their dialogue on the South China Sea and restrain from taking any provocative actions in the area.

The 2002 Declaration absorbed many elements from the previous Chinese proposal, including, but not limited to, the cooperative aspects. China's signature can be regarded as a good gesture to show China's willingness to resolve the South China Sea issue by peaceful means. After the signing of the declaration, China and the Philippines downplayed their navy drills, stating that they were not related to the maritime territorial disputes. 
However, the recent shift in China's attitude from multilateralism back to bilateralism gives the world a negative signal. As China's former ambassador to ASEAN, Xue Hanqin, once stated, because ASEAN members include both claimant and non-claimant states, it was not an appropriate venue to discuss the South China Sea issue and the Chinese government wanted to resolve the territorial disputes through bilateral negotiations. ${ }^{25}$ These remarks indicate that China is attempting to go back to bilateralism in dealing with the South China Sea issue. This turnback is somewhat surprising since China not long ago firmly supported the declaration as its gesture to conform to multilateralism and hosted several implementation meetings in China. The question is whether bilateralism can really work to resolve the South China Sea issue.

On the other hand, the attitude of China towards the South China Sea issue is crucial as China is the most important player in maintaining peace and security in the region. It would be worrying if China took a hard line approach to the South China Sea issue. In testimony to Congress on 13 January 2010, the American armed forces' Pacific Commander, Admiral Robert Willard, said the Chinese navy had increased its patrols in the South China Sea and had 'shown an increased willingness to confront regional nations on the high seas and within the contested island chains' (Economist 2010). If this described scenario proves to be true, then worries from Southeast Asian nations will certainly rise, damaging the spirit and letter of the 2002 Declaration.

Recent incidents in the South China Sea have caused concern by the world community about China's behaviour in conducting international relations. The old topic of the 'China threat' may re-emerge due to China's increasing assertiveness in dealing with the South China Sea issue. On the other hand, China considers the recently more active involvement of the US in the South China Sea as disrupting the harmony of the region.

Based on the doctrine of harmonious world/Asia, China put forward a proposal for joint development in the South China Sea. However, this proposal, though a viable temporary solution to diffuse the tensions in the South China Sea, contains China's self-interest in sharing commercial and resources benefits extracted from the South China Sea. Since it is based on self-interest and therefore appears to lack a 'high moral value', it is naturally not accepted by other claimants, thus greatly hampering China's efforts to build a harmonious Asia or harmonious South China Sea. 


\section{Human Rights Considerations}

In addition, China has reservations about the concept of 'responsibility to protect'. ${ }^{26}$ In the discussion on the issue of 'protection of persons in the event of disasters' at the 6th Committee of the 63rd Session of the UN General Assembly on 3 November 2008, the Chinese delegation decided not to introduce this concept into the area of disaster relief since there were controversies as to its connotation and applicability. ${ }^{27}$ According to a Chinese legal scholar and senior diplomat, the concept may suggest that 'any state could step in and take action against another state when the situation, in its opinion, constitutes a violation of human rights in the territory of the latter state. Obviously, this would be even more intrusive than the traditional theory of humanitarian intervention', and 'any unduly broad and unlimited claim for responsibility to protect may only result in undesired intervention' (Xue Hanqin 2007: 90). Related is China's human rights record, which is usually described as poor despite the fact that China has acceded to a number of international treaties on human rights. It is clear that respect for human rights is a prerequisite for building a harmonious world.

In recent years, some Chinese scholars have tried to rethink the doctrine of 'harmonious world', believing that this diplomatic philosophy based on an idealistic doctrine needs a reasonable adjustment. The international society is in an anarchical state and there is no authority to enforce law; the nature of the international society is based on power to distribute interests; therefore it is not effective for a country to introduce its domestic policy (building a harmonious society) to its foreign affairs. Harmony and lasting peace cannot rely on international economic cooperation (see Deng Yiwen 2011). While adhering to idealism, realism is indispensable in making diplomatic strategy and policy and maintaining national interests (ibid). Recent setbacks have shown that the real world is going away from China's idealism of 'harmonious world'. It is questioned whether China can promote harmony by giving away benefits (Shi Zhiyu 2011). A unilateral giving-away of benefits cannot promote the policy of harmony; superficial harmony based on giving is very fragile in the face of mutual suspicion and deception in international politics (ibid). But on the other hand, does the display of assertiveness work in China's international relations? 


\section{Final Remarks}

There is no doubt that a harmonious world needs a well-articulated order. It is an imperative task for China to promote and develop the international order so as to build the idealistic harmonious world it advocates. In this respect, China's contributions are indispensable and will benefit both the world community and its continuing rise. As a big country, China's rising is understandable and reasonable. The rising of China is actually the 're-emergence' as a big power since China generated the largest share of products and wealth for eight of the past ten centuries (Lipman 2009: 32). Furthermore, 'China absolutely needs peace for its development, without peace its development could be put in jeopardy and gains made in the past three decades could easily be forfeited. China is fully aware that a series of simple and serious mistakes could easily dent and destroy a national position and wealth'. ${ }^{28}$ The promotion of a harmonious world serves China's peaceful development aims. During the 12th Five-Year Plan (2011-2015) period, China's diplomacy targets the following six areas: development, big power relations, promotion of neighbourly cooperation and mutual trust, consolidation and cooperation of developing countries, reform of the international system, and ideational mechanism innovation (Yang Jiechi 2011: 3-4).

It is claimed that the diplomatic activities of 'harmonious world' are forceful countermeasures to the 'China threat' or 'China hegemony' (Li Baozheng 2010: 103). However, it is questionable whether the Chinese assertiveness in recent years, particularly in the South China Sea, is a reflection of the doctrine of harmonious world or whether it is favourable to build a harmonious world/ Asia as China has advocated. It seems that recently, a richer China is becoming more assertive in dealing with international affairs while internally it is more benevolent towards its people. An image of too much assertion may not help to realize China's idealistic goal of turning both the East China Sea and the South China Sea into seas of peace, cooperation and harmony. For that reason, there may be a need to introduce some kind of 'smart power' into China's foreign policy considerations. It could reasonably be expected that a big power like China could set a good example that other fellow countries could follow to collectively maintain long-term regional peace and security.

Although China is no doubt playing a more active and on some occasions critical role in international affairs, China is not yet a global power that can direct the course of change in the international order. It is certain that China is a maintainer and supporter of the current world order, 
rather than a challenger to it. This can be seen from Chinese statements made at the United Nations forum that the authority of the UN Charter must be maintained and 'defending the authority of the Charter is essential for maintaining the rule of law at the international level' (Duan Jielong 2007: 187). China is generally satisfied with its current position in the existing international system. In this context, I agree with G. John Ikenberry that China 'is increasingly working within, rather than outside of, the Western order'(Ikenberry 2008), although I do not like his term 'Western order' since the current international order is obviously not purely Western.

While China demands a bigger and more vigorous say, it should consider whether it is ready to assume more responsibilities in world affairs. It is rightly pointed out that 'power comes with responsibility. China's rising status in the international community provides it with greater influence and benefits; at the same time, it demands greater responsibility, including demonstration that it complies with international rules and practices that, in turn, may impose constraints and costs' (Jing-dong Yuan 2008: 66). It is really a challenge to China to assume its global responsibilities, such as to respect universal human rights.

China has realized that there are many inharmonious factors in today's world and there is a lot of work to do to reach the 'harmonious world' (Wu Jianming 2009: 19). It is not easy to build a harmonious world in a world of great disharmony; the harmonious world is a long process to promote the development of a new type of international relations and order (Zhang Yunlin 2008: 12). For China itself, it is suggested that if China wants to realize the dream of a harmonious world, there are three unavoidable steps China must take: (1) to have a clearer vision of China's own identity and what kind of society it wants to be; (2) to have a clearer vision of what kind of international society China wants to promote; and (3) to have a strategy for creating a proper reconciliation with Japan, at the level of peoples and not just of governments (Buzan 2010:36). Despite the assertion that a 'harmonious world' is not a Utopian ideal, rather it is a pragmatic foreign policy (Shi Yinhong 2007: 10), it is assumed that this ideal could turn out to be a mission impossible since there is so much uncertainty within and outside China, among which many elements are beyond the control of the Chinese government. It is common in human society that things go contrary to one's wishes.

Finally, there is a call in China for the abolition of the slogan 'building a harmonious society' as it is out-of-date and not conducive to the maintenance of the societal order in China. Unrest in China is even 
more rampant than before the introduction of the harmonious society concept. In the view of some critics, the construction of a harmonious society has failed as the country treats it as the top value, equivalent to 'stability is everything'. As a result, superficial harmony and temporary stability sacrifice fairness and justice, thus the whole society is becoming more disharmonious and more unstable. For that reason, the expression 'harmonious society' should be replaced by a universally used expression, such as 'just society' or 'civil society'. ${ }^{29}$ As the 'harmonious world' doctrine is closely associated with that of 'harmonious society', if the doctrine of 'harmonious society' proves to be a failure in practice, how can the former survive once the latter is abolished? Nevertheless, as the Chinese government continues to advocate a harmonious society in China, as reflected in the latest White Paper, it is safe to say that success in building a harmonious world depends on the success of building a harmonious society within China. How can people evaluate this legacy of the $\mathrm{Hu}$-Wen administration? This article provides some preliminary observations and attempts to promote more valuable discussion in the years to come.

Zou Keyuan is Harris Professor of International Law, University of Central Lancashire, UK, and Research Associate, East Asian Peace Program, Uppsala University, Sweden.

\section{NOTES}

1 This article is based on my paper presented to the East Asian Peace Program First Annual Conference on Democracy and Peace in East Asia, organized by the Department of Peace and Conflict Research, Uppsala University, Sweden, 16-18 September 2011. The author appreciates the helpful comments from the two anonymous reviewers but assumes the sole responsibility for any possible errors in the article.

2 See Article 2 of the Charter of the United Nations. The text of the Charter is available at http://www.un.org/en/documents/charter/chapter1.shtml.

3 As Article 4 of the UN Charter states, UN membership is open to those nations that accept the obligations contained in the Charter and are able and willing to carry out those obligations.

4 It is reported that the first time Chinese President Hu Jintao put forward the idea of constructing'a harmonious world' was on 28 May 2003 when he made a speech to the Institute of International Relations in Moscow. The idea was reiterated at the Asia-African Summit in Jakarta in April 2005 (see Zhang Xiaobing 2009: 33).

5 The whole text of the white paper can be found at: http:/ / www.china.org.cn/english/2005/Dec/152669.htm.

6 The whole text of the Plan (in Chinese) is available at: http://news.xinhuanet. com/politics/2011-03/16/c_121193916.htm. 
7 It should be noted that the points contained in the latest white paper are the most detailed for the harmonious world doctrine.

8 For more details, see Bo Zhiyue (2004): 1, 10.

9 The four strategies of China's diplomacy, set forth at the 10th Meeting of Diplomatic Envoys in 2004, include: big powers are keys, surrounding areas are priority, developing countries are basis and multilateralism is an important forum.

10 Constitution of the People's Republic of China. Available from http://english. peopledaily.com.cn/constitution/constitution.html (accessed 9 September 2011).

11 It is reported that it was first mentioned at the 4th Session of the 16th Party Congress in September 2004.

12 Text in UNTS 299: 59 (1958).

13 In 2004, China commemorated the 50th anniversary of the Five Principles of Peaceful Coexistence and some speeches made on that occasion, including the speech by Prime Minister Wen Jiabao, were published in Chinese Journal of International Law 3(2): 363-377.

14 Some discussions on the cultural factors concerning the doctrine of 'harmonious world' can be found in Yu Bin 2008: 119-135.

15 For China's efforts in Africa, also see Masuda Masayuki 2009.

16 More precisely, 9.1\%,10\%,10.1\%,10.4\%,11.6\%,13\% and 9\% in the successive years from 2002 to 2008. See the 2006 National Economic and Social Development Statistical Announcement, 30 April 2007. Available from: http://www.fdi.gov.cn/pub/ FDI/zgij/tzhj/hgij/gmjjyshfz/t20070430_77928.htm (accessed 8 July 2007), and the 2008 National Economic and Social Development Statistical Announcement, 26 February 2009. Available from: http://www.stats.gov.cn/tjgb/ndtjgb/qgndtjgb/ t20090226_402540710.htm (accessed 5 July 2009).

17 See annual World Investment Reports published by the World Bank.

18 See 'Position Paper of the People's Republic of China at the 63rd Session of the United Nations General Assembly', 16 September 2008.

19 'White paper on national defense published'. Available from: http://www.china. org.cn/government/central_government/2009-01/20/content_17155577_15.htm (accessed 26 October 2009).

20 UN Doc S/RES/1816 (2008), 2 June 2008.

21 See UN Doc S/RES/1816 (2008).

22 'UN meeting calls for help to strengthen the anti-piracy capacity-building of Somalia', 12 December 2008, National Institute for South China Sea Studies.

23 The two proposals and the drafts of the Code of Conduct both from ASEAN and China are reprinted (in Chinese) in Hainan Research Institute for the South China Sea 2002: 180-183.

24 The whole text is available in the ASEAN website: www.asean.org.

25 'Beijing: South China Sea Territorial Disputes Not on ASEAN Agenda', VOA News. com, 21 October 2009, available from: www.voanews.com.

26 It is argued that'State sovereignty implies responsibility, and the primary responsibility for the protection of its people lies with the state itself. Where a population is suffering serious harm, as a result of internal war, insurgency, repression or state failure, and the state in question is unwilling or unable to halt or avert it, the principle of non-intervention yields to the international responsibility to protect'. (International Commission on Intervention and State Sovereignty 2001: xi)

27 See'Statement by H.E. Ambassador Liu Zhenmin, Deputy Permanent Representative of China to the UN, at the Sixth Committee of the 63rd Session of the UN General Assembly, on Item 75: Report of the International Law Commission on the Work of its 60th Session -- Part Three', 3 November 2008, available from: http://www. 
china-un.org/eng/hyyfy/t520980.htm (accessed 29 October 2009).

28 Francesco Sisci,'China and the Status Quo - Part I', The Global Realm, 12 April 2011. Available from: http:/ / theglobalrealm.com/2011/04/12/china-and-the-status-quopart-i (accessed 11 July 2011).

29 Hu Xingdou,'Proposing to abolish the expression'harmonious society", 15 July 2011. Available from: http://news.boxun.com/news/gb/pubvp/2011/07/201107151541. shtml (accessed 15 July 2011).

\section{REFERENCES}

Blanchard, Jean-Marc F. 2008. 'Harmonious World and China's Foreign Economic Policy: Features, Implications, and Challenges'. Journal of Chinese Political Science 13(2): 165-192.

Bo Zhiyue. 2004. 'Elite Politics and the "Peaceful Rise" of China'. EAI Bulletin 6(2): 1, 10.

Buzan, Barry. 2010. 'China in International Society: Is "Peaceful Rise" Possible?' Chinese Journal of International Politics 3: 5-36.

Chen Xiangyang. 2009. 'Direction of China's Grand Diplomacy in the New Time'. Outlook News Weekly, 28 July. Available from: http:/ / www.zaobao.com.sg/wencui/2009/07/liaowang090728g.shtml (accessed 28 July 2009).

Confucius. 1993. The Analects. Translated by Raymond Dawson. New York: Oxford University Press.

Deng Yiwen. 2011. 'China's diplomatic philosophy needs appropriate adjustment'. Lianhe Zaobao, 6 July. Available from: http://www/zaobao.com/yl/tx110706_001. shtml (accessed 6 July 2011).

Dodge, David, and John Murray. 2006. 'The Evolving International Monetary Order and the Need for an Evolving IMF'. Global Governance 12: 361-372.

Duan Jielong. 2007. 'Statement on the Rule of Law at the National and International Levels'. Chinese Journal of International Law 6: 185-188.

Economist. 2010. 'Choppy waters: East and south, China makes a splash', January 21. Available from: http:/ / www.economist.com/world/asia/displaystory.cfm?story_ id=15331153 (accessed 15 February 2010).

Hainan Research Institute for the South China Sea (ed). 2002. Selected Foreign and Chinese Articles on the South China Sea (2001), (in Chinese). Hainan, China: Hainan Research Institute for the South China Sea.

Halvorssen, Anita M. 2007. 'Climate Change Regime-Amending the Kyoto Protocol to Include Annex C and the Annex D Mitigation Fund'. Colorado Journal of International Environmental Law and Policy 18(2): 247-265.

Han, Ai Guo. 2008. 'Building a Harmonious Society and Achieving Individual Harmony'. Journal of Chinese Political Science 15(2): 143-164.

'Harmonious World: China's Ancient Philosophy'. 2007. Available from http:// mu.china-embassy.org/eng/xwdt/t369665.htm (accessed 11 July 2011).

Hu Jintao. 2005. 'Making efforts to build a harmonious world with lasting peace and common prosperity'. People's Daily, 16 September.

$\mathrm{Hu}$ Jintao. 2007. 'Highly Holding the Great Banner of Socialism with Chinese Characteristics, Striving for New Victories in Comprehensively Building an Affluent Society'. Report to the 17th Party Congress, 15 October 2007. Available from: http://www. china.org.cn/english/congress/229611.htm (accessed 11 September 2011).

$\mathrm{Hu}$ Jintao. 2009. Speech at the Opening Plenary Session of the United Nations Summit on Climate Change', 23 September. Available from: http:/ / www.china-un.org/eng/ 
zt/hu2009summit/t606111.htm (accessed 2 November 2009).

Ikenberry, John G. 2008. 'The Rise of China and the Future of the West'. Foreign Affairs 87(1): 23-37.

Information Office of the State Council. 2011. White Paper on Peaceful Development. Available from: http://www.chinese-embassy.org.uk/eng/zgyw/t856325.htm (accessed 9 September 2011).

International Commission on Intervention and State Sovereignty. 2001. The Responsibility to Protect (Report of the International Commission on Intervention and State Sovereignty). December 2001.

Jia Qingguo. 2003. 'China'. In Humanitarian Intervention: The Evolving Asian Debate, Watanabe Koji (ed), 19-32. Tokyo: Japan Center for International Change.

Li Baozheng. 2010. 'From Advocating "Peaceful Coexistence" to Building a "Harmonious World"' (in Chinese). In Chinese Communist Party and Contemporary Chinese Diplomacy, Qi Pengfei (ed), pp. 64-103. Beijing: Chinese Communist Party History Publisher.

Lipman, Jonathan. 2009. 'The "Rise" of China: Continuity and Change'. In Global Giant: Is China Changing the Rules of the Game?,Eva Paus, Penelope B. Prime, and Jon Western (eds.), pp. 29-47. Hampshire: Palgrave MacMillan.

Liu Dongguo. 2009. 'The Significance of the Transformation of China's Development Model for the Construction of a Harmonious World'. Explore (tanshuo) 5: 32-43.

Masuda Masayuki. 2009. 'China's Search for a New Foreign Frontier: Concept and Practice of 'Harmonious World". In China's Shift: Global Strategy of the Rising Power, Masafumi Iida (ed.), pp. 57-79. NIDS Joint Research Series No. 3. Tokyo: National Institute for Defence Studies.

Pan Jiahua. 2009. 'Harmonious Competition: the Tune of Sino-US Climate Cooperation' (hexie jingzheng: zhongmei qihou hezuo de jidiao). China Party Official Forum (zhongguo dangzheng ganbu luntan) 9: 42-44.

Pan Junwu. 2010. 'Chinese Philosophy and International Law'. Asian Journal of International Law 1 (2): 1-16.

Paus, Eva, Penelope B. Prime, and Jon Western. 2009. 'China Rising: A Global Transformation?' In Global Giant: Is China Changing the Rules of the Game?, Eva Paus, Penelope B. Prime, and Jon Western (eds.), pp. 3-27. Hampshire: Palgrave MacMillan.

People's Daily. 2007. 'Our Foreign Minister expounds China's position on the issues of North Korean nuclear and climate change' (in Chinese), 2 August.

People's Daily. 2009a. 'World Bank and IMF reiterate the increase of rights to say for the developing countries' (in Chinese), 6 October.

People's Daily. 2009b. 'China has made six measures to help developing countries' (in Chinese), 22 September.

Sheng Ding. 2008. 'To Build a "Harmonious World": China's Soft Power Wielding in the Global South'. Journal of Chinese Political Science 13(2): 193-213.

Shi Yinhong. 2007. "'Harmonious World" is Pragmatic Foreign Policy'. China Daily, 5 July, p. 10. Available from: http://www.chinadaily.com.cn/china/2007-07/05/ content_6142399.htm (accessed 11 September 2011).

Shi Zhiyu. 2011. 'Can Beijing promote harmony by giving benefits?' Lianhe Zaobao, 23 August. Available from: http://www.zaobao.com/yl/tx110823_002.shtml (accessed 23 August 2011).

Su Hao. 2009. 'Harmonious World: The Conceived International Order in Framework of China's Foreign Affairs'. In China's Shift: Global Strategy of the Rising Power, Masafumi Iida (ed.), pp. 29-55. NIDS Joint Research Series No. 3. Tokyo: National Institute for Defence Studies.

United Nations. 2008. 'Security Council Condemns Acts of Piracy, Armed Robbery off Somalia's Coast, Authorizes for Six Months "All Necessary Means" to Repress 
Such Acts'. SC/9344, 2 June. Available from: http://www.un.org/News/Press/ docs /2008/sc9344.doc.htm (accessed 23 October 2008).

Vatikiotis, Michael R. J. 2003. 'Catching the Dragon's Tail: China and Southeast Asia in the 21st Century'. Contemporary Southeast Asia 25(1):65-78.

Wang Tieya (ed). 1995. International Law (in Chinese). Beijing: Law Press.

Wen Jiabao. 2004. 'Carrying Forward the Five Principles of Peaceful Coexistence in the Promotion of Peace and Development'. Speech at the Rally Commemorating the 50th Anniversary of the Five Principles of Peaceful Coexistence, 28 June. Available from: http://www.fmprc.gov.cn/eng/topics/seminaronfiveprinciples/t140777. htm (accessed 17 June 2008).

Wu Jianming 2009. 'From "Small Diplomacy" to "Big Diplomacy"' (cong xiao waijiao dao da waijiao). Beijing Daily, 13 July.

Xinhua News Agency. 2005. 'Hu Makes 4-point Proposal for Building Harmonious World', 16 September. Available from: http:/ / www.china.org.cn/english/features/ UN/142408.htm (accessed 11 July 2011).

Xue Hanqin 2007. 'Chinese Observations on International Law'. Chinese Journal of International Law 6:83-93.

Yang Jiechi. 2011. 'The Evolution of the Contemporary International Structure and China's Foreign Affairs' (dangqian guoji geju de yanbian he woguo waijiao gongzuo), Studies on International Issues (guoji wenti yanjiu) No.1: 1-4.

Ye Qing. 2011. 'From War and Revolution to Harmonious World: Evolution of CPC's Concept of Main Theme of Times and China's Diplomacy'. Global Review (guoji zhanwang) 4 (July-August): 2-18.

Yu Bin. 2008. 'China's Harmonious World: Beyond Cultural Interpretations'. Journal of Chinese Political Science 13(2): 119-135.

Yuan, Jing-dong. 2008. 'The New Player in the Game: China, Arms Control, and Multilateralism'. In China Turns to Multilateralism: Foreign Policy and Regional Security, Guoguang $\mathrm{Wu}$ and Helen Lansdowne (eds.), pp. 51-72. London: Routledge.

Zhang Xiaobing. 2009. 'China's Position in Hu Jintao's Era'(hujintao shidai guan de zhongguo zhuzhang). Outlook Weekly (Beijing) 47: 32-36.

Zhang Yunlin. 2008. 'Firmly Following the Road of Opening to the Outside and Peaceful Development'. World Economics and Politics 11: 6-11.

Zheng Yongnian and Sow Keat Tok. 2007. "'Harmonious Society" and "Harmonious World": China's Policy Discourse under Hu Jintao'. Briefing Series - Issue 26, October. Nottingham: China Policy Institute, University of Nottingham. 